\title{
DEVELOPING INTERCULTURAL COMPETENCE: A MODEL BASED ON INTRODUCING A LITERARY ANALYSIS IN A FOREIGN LANGUAGE CLASSROOM
}

\author{
DESENVOLVENDO COMPETÊNCIA INTERCULTURAL: UM MODELO BASEADO \\ NA INTRODUÇÃO DE UMA ANÁLISE LITERÁRIA EM UMA SALA DE AULA DE \\ LIINGUA ESTRANGEIRA
}

\section{DESARROLLO DE LA COMPETENCIA INTERCULTURAL: UN MODELO BASADO EN INTRODUCIR UN ANALISIS LITERARIO EN UN AULA DE LENGUA EXTRANJERA}

\author{
Anfisa N. IBRAGIMOVA ${ }^{1}$ \\ Alina A. KADYROVA ${ }^{2}$
}

\begin{abstract}
This article is concerned with developing students' intercultural competence through teaching literary analysis as a part of teaching foreign languages and linguistics in higher education. The objective of the research is to design a model of developing intercultural competence through literary analysis in a foreign language class. Modelling was applied as the leading method of the research as it regards the process of IC (intercultural competence) development as a task-oriented and organized pedagogical process. The submitted didactic model should develop the IC through knowledge, skills, a system of values, reflection and positive attitude to the culture under study, so it includes components such as objectives, motivation, organization, content, and evaluation; it determines the pedagogical conditions, organization, teaching methods and tools that together provide the targeted result. The formative experiment introduced the model into practice in a foreign-language class at university and showed positive results in developing the students' intercultural competence. The model provides pedagogical support of the process of developing IC as a part of foreign language teaching and can be applied within language, literature and linguistics-related courses.
\end{abstract}

KEYWORDS: Intercultural communication. Education. Student. Intercultural competence (IC). Literary analysis. Foreign language. Pedagogic modelling. Humanities.

RESUMO: Este artigo se preocupa em desenvolver a competência intercultural dos alunos por meio do ensino de uma análise literária como parte do ensino de línguas estrangeiras e linguística no ensino superior. O objetivo da pesquisa é desenhar um modelo de desenvolvimento da competência intercultural por meio de uma análise literária em uma aula de língua estrangeira. A modelagem foi aplicada como o método principal da pesquisa, pois considera o processo de desenvolvimento de CI (competência intercultural) como um processo pedagógico organizado e orientado para a tarefa. O modelo didático apresentado deve desenvolver a CI por meio de conhecimentos, habilidades, um sistema de valores, reflexão e

\footnotetext{
${ }^{1}$ Kazan Federal University (KPFU), Kazan - Russia. ORCID: https://orcid.org/0000-0001-8039-8642. E-mail: busybeetime@gmail.com

${ }^{2}$ Kazan Federal University (KPFU), Kazan - Russia. ORCID: https://orcid.org/0000-0003-1232-6852. E-mail: busybeetime@gmail.com
} 
atitude positiva em relação à cultura em estudo, de modo que inclua componentes como objetivos, motivação, organização, conteúdo e avaliação; determina as condições pedagógicas, a organização, os métodos e ferramentas de ensino que, em conjunto, fornecem o resultado pretendido. A experiência formativa introduziu o modelo em prática em uma aula de língua estrangeira na universidade e mostrou resultados positivos no desenvolvimento da competência intercultural dos alunos. O modelo fornece suporte pedagógico para o processo de desenvolvimento de CI como parte do ensino de línguas estrangeiras e pode ser aplicado em cursos de línguas, literatura e relacionados à linguística.

PALAVRAS-CHAVE: Comunicação intercultural. Educação. Estudante. Competência intercultural (CI). Análise literária. Língua estrangeira. Modelagem pedagógica. Humanidades.

RESUMEN: Este artículo se ocupa del desarrollo de la competencia intercultural de los estudiantes a través de la enseñanza de un análisis literario como parte de la enseñanza de lenguas extranjeras y lingüistica en la educación superior. El objetivo de la investigación es diseñar un modelo de desarrollo de la competencia intercultural a través de un análisis literario en una clase de lengua extranjera. El modelado se aplicó como método principal de la investigación en lo que se refiere al proceso de desarrollo de la CI (competencia intercultural) como un proceso pedagógico organizado y orientado a tareas. El modelo didáctico presentado debe desarrollar el CI a través de conocimientos, habilidades, un sistema de valores, reflexión y actitud positiva hacia la cultura en estudio, por lo que incluye componentes tales como objetivos, motivación, organización, contenido y evaluación; determina las condiciones pedagógicas, la organización, los métodos de enseñanza y las herramientas que, en conjunto, proporcionan el resultado deseado. El experimento formativo introdujo el modelo en práctica en una clase de lengua extranjera en la universidad y mostró resultados positivos en el desarrollo de la competencia intercultural de los estudiantes. El modelo proporciona apoyo pedagógico al proceso de desarrollo de CI como parte de la enseñanza de lenguas extranjeras y puede aplicarse en cursos relacionados con la lengua, la literatura y la lingüística.

PALABRAS CLAVE: Comunicación intercultural. Educación. Estudiante. Competencia Intercultural (IC). Análisis literario. Lengua extranjera. Modelización pedagógica. Humanidades.

\section{Introduction}

The modernized education proclaims a competence-based approach as one of the most important concepts of the education renewal. The importance of competencies concerning culture is hard to be overprized. Nevertheless, there is no consensus on the terminology around intercultural competence (DEARDORFF, 2011). The acquisition of intercultural competence is never complete and perfect but being a successful intercultural speaker and mediator does not require complete and perfect competence (BYRAM; GRIBKOVA; STARKEY, 2002). 
The Council of Europe defines intercultural competence as "The components of intercultural competence are knowledge, skills, and attitudes, complemented by the values a person holds as a part of belonging to some social groups (Council of Europe). These values are also parts of a person's social identities. Discussing the intercultural competence in educational settings, Alvino Fantini writes the following: 15 "In this construct of ICC, there are also five dimensions. These are awareness, attitudes, skills, knowledge, and proficiency in the host tongue (FANTINI, 1999).

So, learning a foreign language is one of the key components of intercultural competence and, if we turn our views over literature as a part of a language teaching process, we may consider its possibilities in terms of IC development (ABUZYAROVA; TAKHTAROVA; KUZMINA, 2019; SABIROVA et al., 2019). Following Rakhimov's studies, a foreign literary text as a unit of culture; a method of passing on communal experience; implied information that needs specific decryption; a way of self-cultivation through the choice of content; the object of understanding and acquisition; means of developing intelligence; a means of reflective thinking; means of result-oriented development and building up creative thinking and aspiration for creative activity (RAKHIMOV, 1996).

Literature has always been a part of traditional teaching in a foreign language classroom as a means of presenting people's views over this world, a piece of art, an example of some grammar structures and lexis, as a source for discussion about anything and everything in our life. Then the classic pieces of literature disappeared from classrooms as their vocabulary became obsolete (DIMITROVA-GYUZELEVA, 2015). Fortunately, the scientists and foreign language teachers unexpectedly found in authentic literature background for developing culture and communication-related competences: intercultural, socio-cultural, socio-linguistic and other. The didactic function of literature is that it can serve an objective and means of teaching as a subject of interpretation (literary, intercultural, sociolinguistic, etc) that determines the way of working with it. To make full use of the didactic possibilities of the authentic piece of literature, we've designed a didactic model that ought to follow the didactic principles and pedagogic conditions to develop the IC of a personality.

Therefore, analyzing the essential embodiment of an artistic book and its function, we may suppose that the text by the very nature can possibly build up all the elements of intercultural competence (knowledge, attitudes, skills, values, and reflection). 


\section{Methodological framework}

\section{The methods of the research}

The research of developing IC was based on analyzing the educational, psychological, methodological, linguistic and culture-related study on developing intercultural competence and communication; studying national and foreign language coursebooks, literary analysis and guides; pedagogic modeling, various kinds of pedagogic experiment: observation, survey, interviewing, table discussion and expert evaluation; the students' performance; Student's t-test. In the course of the experiment we set the objective to a) select the content, forms, methods to develop intercultural competence of the university students; to approbate the pedagogical means of building intercultural competence among students; b) assess the effectiveness of the developed model to build the intercultural competence in the process of working with the course of Text Analysis; c) assess the effectiveness of the pedagogical conditions to develop intercultural competence while studying the discipline "Interpretation of the text".

To obtain the data of the experiment the authors used questioning, expert evaluation form interviews, participant and non-participant observations, analysis of intellectual creation. The expert evaluators were 4 professors of Kazan Federal University. As an independent variable, there were the pedagogical conditions aimed at developing intercultural competence, and as the dependent variable, there was the level of intercultural competence, i.e. the skills that the students have mastered.

The main experimental work was carried out on the basis of Kazan Federal University during the year. Kazan is a city in the heart of Russia that is famous for diverse cultures coexisting peacefully at the same place. The students' native languages are various, some of them are bilingual, but for all of them, English is a foreign language. There were 63 students engaged in the experiment. The experiment was performed in an English-language classroom and included 76 academic hours for studying a literary analysis and interpretation within a foreign language classroom. All the students of these groups are Russian-speaking ladies about 20 years old. The gender was conditioned by the specificity of their major - Psychology. A few of them have been abroad for a short period (tourism) and 2 students have studied abroad during school-time.

The study included three stages. At the first stage we analyzed the extent of the previous investigation concerning the ways of defining, developing and assessing students intercultural competence, studied the programs of developing IC within university education; then defined 
the research topic, its relevance, practical significance, determined the basic tasks and pedagogical conditions, designed the program of the pilot experiment.

At the beginning of the study, the students were divided into 2 groups and offered a questionnaire about common cultural features of the English and American cultures. After the experiment at the end of the course, the students answered the same questions. The results were fixed and analyzed.

At the second stage, we designed a model of developing IC in course of teaching a literary analysis within foreign language teaching; we selected the literature for students to work with, the forms and tools of teaching; tested the pedagogic means; examined the efficiency of the developed model and pedagogic conditions. Pedagogic modeling of the pedagogic systems is performed by structuring the content. This assumes definition, explanation, modification, and improvement of the newly constructed frameworks. Modeling in education has two aspects: modeling as content that the learners should acquire and model as an educational tool. Modeling is one of the most efficient modes of learning any new skill or knowledge (BANDURA, 1986). By modeling, it is possible to convert complex issues into uncomplicated ones, hidden and vague into evident and real, unfamiliar into familiar. Modeling offers acquiring new information, skills or behavior through observation, rather than through direct experience or trial-and-error efforts. Learning is viewed as a function of observation, rather than direct experience (HOLLAND; KOBASIGAWA, 1980).

The growing amount of research devoted to intercultural competence, its components, characteristics, and assessment has created multiple iterations of its definition, so we consider Deardorff's summary: "Knowledge of others; knowledge of self; skills to interpret and relate; skills to discover and/or to interact; valuing others' values, beliefs, and behaviors; and relativizing one's self. Linguistic competence plays a key role" (CEFR, 2001). So having analyzed the concept and the components of IC (BYRAM; NICHOLS; STEVENS, 2001; FANTINI, 1997) we made a conclusion that the model should grant knowledge, skills, value orientations and positive attitude of a student toward the culture of study.

Then we designed the model using systemic, activity and cultural approaches. The systemic approach views the process of developing IC as an integrated system with specific relations between its components. The activity approach allows organizing the work as dynamic interaction of its members of the educational process. The cultural approach facilitates acquiring cultural implications, students' integration into the system of culture.

This analysis allows performing the process of developing IC as a complex multilevel process consisting of motivational, contextual, organizational and evaluative components the 
interaction and integration of which enables the acquisition of intercultural knowledge and skills for effective intercultural communication. A model is shown in Figure 1.

Figure 1 - Developing intercultural competence model

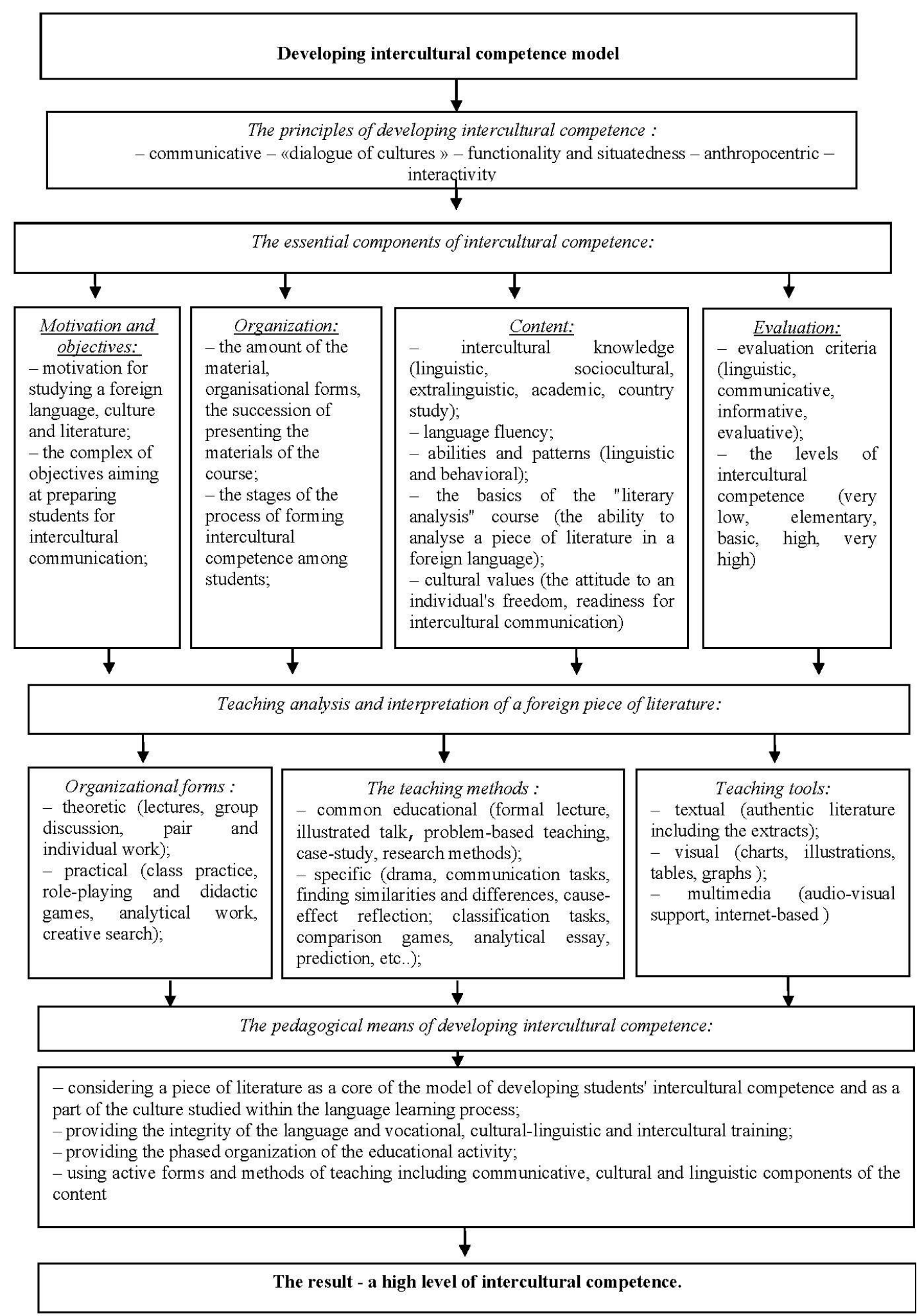

Source: Prepared by the authors 
A literary text as a unique communicative unit that influences both knowledge and attitude components of intercultural competence and represents one of the elements that may contribute to its development, so treating a literary text like a speech unit makes it reasonable to follow the principles of communicative approach as a foreign language teaching method such as the principle of functionality and sociocultural situatedness, interactivity, "dialogue of cultures", communicative and anthropocentric principles (PASSOV, 1985).

The communicative principle means constant practical use of the language in speech. Benveniste said that a speech creates a language and there is nothing in the language that was not in the speech before. Nowadays, no teacher who is eager to help students to acquire a foreign language can avoid intercultural phenomena. Just speaking in a classroom about a cultural phenomenon in a language of this culture is similar to speak about a language phenomenon in this language - neither first nor second develops students' skill in communicating with the representatives of other cultures (ABUZYAROVA; TAKHTAROVA; KUZMINA, 2019).

The anthropocentric principle is applied within a humanistic approach to language teaching and promotes the intellectual and emotional development of a personality. This principle allows taking into consideration, the psychological factors of the communication tasks concerning the student's personality without judgment, accepting the personality and uniqueness of every participant of the active process of learning that facilitates the student's self-actualization and development of interpersonal relationships. The student becomes the center of cognition at the lesson. This principle demands attention to the presentation of the material according to the speaking and cognitive abilities of the speaker; the relationships are built on non-judgment, non-criticism and empathy. There may appear some speech mistakes and slips of the tongue. It should be mentioned that speech mistakes in real communication are possible as communicative grammar allows deviations from written grammar (interrupted utterances, emphatic sentences, etc.).

The principle of functionality implies that any speech form and unit performs some communicative function in the process of communication. It is very important to make conditions for recreating the communicative environment during teaching literary analysis in a foreign language classroom. The principle of situationality supposes accepting a situation as a unit of teaching process organization.

The principle of interactivity means the continuous interaction of the students with each other and the teacher. But the situations created intentionally during the study are not equal to intercultural situations if the participants are the representatives of the same culture. In this case, we may consider it only as a preparation for intercultural communication. 
The essential components of intercultural competence include objectives, motivation, context, organization, and evaluation. The motivation and objectives of the didactic model incorporate the complex of tasks to acquire language and culture based on interest to this knowledge, expectation in global communication. The organizational component includes teaching principles, the forms, and methods of teaching and studying and some training facilities. The teaching process of a literary text analysis includes such forms as a lecture (theoretical aspects of the discipline), group discussion, role-play, individual and pair work. Since it is not always possible to provide real intercultural communication the teacher should try to create the atmosphere as close to the conditions of real communication as possible.

The contextual component incorporates knowledge and skills related to the culture under study (linguistic, culture-study, socio-linguistic, extralinguistic, etc.) and the course of "a literary analysis", connected to the existing values of the culture (and attitude to any other culture also).

So, the student should know:

- general information (history, economy, far climate, state system, etc.) historic dates of the epic events, the mundane facts (the education system, mass-media,etc ); famous people, the events of social life, etc; the features of the social psychology and patterns of behavior; the stereotypes of the nation if there are any;

- the awareness of everything that composes the culture: the national communication culture, etiquette, the living conditions of the native speakers, their system of values. mentality, national character, etc.

The values-related knowledge assumes the awareness of the culture-bearers' approach to values (not the same as to a different culture). For example, the relationships inside a family, attitude to history, monuments, time; national conflicts inside culture; awareness of such common values as patriotism, duty, loyalty; dealing with urgent challenges of today's life, such as terrorism, anti-drug policy, etc (NIKOLAEVA, 2013).

The knowledge and skills regarding literary analysis include a practical skill to analyze a piece of literature in a foreign language (authentic, non-adapted). It varies according to the objectives and program of the course: composition, title, theme and idea, plot, setting, narration/point of view, characterization, symbol, genre/style, background, historical context; social, political, economic contexts; ideology; various critical orientations; literary theory. All these aspects of analytical reading are studied during the course and have practical importance. 
The contextual component also includes the knowledge and skills in the extralinguistic (non-verbal and paraverbal means of communication) and verbal behavior in intercultural communication. Though some episodes of verbal behavior appear in literature more often than in informative texts. For example, it is not respectable to ask about income and social status, political views and attitude to the death penalty, etc.

1. The main learning tool is a piece of foreign literature while videos, graphics, illustrations are complementary.

For effective work on developing IC, the literary texts as a means of learning are selected in terms of (1) volume, (2) the age of the students, (3) concept (4) the motivational-educational content, (5) the level of language proficiency and (6) language accessibility. The story should meet the students' interests (about culture, life, history of the language, etc.) It is desirable for the low- achieving students when the text contains some features of the nation-specific view over the world.

A piece of literature for further analysis impose the following requirements:

a. The idea should become clear at the end of the story particularly at the early stages of language learning to provide a thorough understanding of the text and to facilitate the entry of the subjects of the learning process in interpreting and analyzing.

b. Volume - a short story, an extract - the texts must be quite large to ensure the repetition of the words, but at the same time be fully self-contained.

c. The ambiguity of the story/extract implies a variety of personal understandings and the desire to compare them to other versions. The motivational and educational potential of a piece of literature contributes to understanding its practical importance and encourages speech activity.

d. The linguistic criterion of choosing a text is closely connected to the students' level of education and age as well as to the conceptual criterion. Understanding the context of the text at all stages must be arranged in such a way that it presents some difficulty to understand, but it is available. And it should be mentioned that text analysis and interpretation are important not only at an explicit but an implicit level of meaning either. And understanding of the story depends on the level of language proficiency.

This aspect has become the ground for the submitted model of developing a new intercultural competence via literary analysis (Figure 1). 
The process of building intercultural competence included many diverse and a few repeated techniques. At the beginning of the course there were a lot of introductory exercises to introduce the way one might work with a foreign text such as information gap (linguistic and cultural studies); tracking the development of the character in the storyline; "predictions" based on speaking names or illustrations; "predicting" the development of the plot with later discussion about being true or not; "Change of perspective" exercise that means to describe the events from another personage; writing a genre story (romance, fantasy, sci-fi, etc.), several stylistic exercises (e.g. The Man Who Saw the Flood by Richard Wright)

Generally, there were 4 groups of exercises within the course:

a) a group of linguistic exercises dealing with the stylistics of the text, its normative usage (slang, violation, etc.), synonyms within the text and word order. The exercises directed at these aspects were to provide a good shift in linguistic aspects.

b) a group of informative exercises dealing with fiction study, historic, cultural and background knowledge. The exercises include disambiguation, various commentaries, exemplification, and extra study. The most common way of work is questioning, information gaps, audio-visual aids.

c) a group of communicative exercises included a wide of range exercises developing reading (scanning, skimming, reading for detail, looking for synonyms, etc.), writing (essays and final analytical paper), speaking and listening (screen adaptation of some stories ( Gone with the Wind and The Hours)).

d) a group of evaluation exercises included the exercises to contrast the points of view, to analyze the background, to dramatize and understand the motives of the personages and authors, etc. These exercises were sometimes misleading and demanded more time because of professional interference of the students' major (psychology). The students were inclined to analyze the psychological background of the personages and fabricate the theme and motives. They were also inclined to explain the conflict of the story with the psychological peculiarities of the personages.

The repeated exercise was intended to develop the particular skill of analyzing text and included some questions to discuss (Attachment 2) before analyzing the story. The general course of text interpretation included the short stories «Cat in the Rain» (Ernest Hemingway), «The One Who Waits» (Ray Bradbury), «I Spy» (Graham Green), «Carcassone» (William Faulkner), «The Man Who Saw The Flood» (Richard Wright), The Last Tea (Dorothy Parker), 
Reunion (John Cheever). The choice of texts was determined by the criteria indicated in the study, so the texts were chosen to provide the material for linguistic, informative-cognitive, speech and evaluative criteria.

For example, I spy by Graham Green is is a great example of how a story can teach to be interculturally polite and tolerant. It demands a deep knowledge of the setting and historical background, it is quite vague a foreigner as there are no bowler hats in our culture and Zeppelins, Gold Flake and Players need special deciphering and explanation. The story is emotional as the narrator is a frightened boy who learned the greatest mystery.

Table 1 - The levels of Intercultural Competence

\begin{tabular}{|c|c|c|c|c|}
\hline Low level & $\begin{array}{l}\text { Understands basic } \\
\text { texts. Shows little } \\
\text { linguistic } \\
\text { awareness (word } \\
\text { order, normativity, } \\
\text { textual levels) }\end{array}$ & $\begin{array}{l}\text { Possesses limited knowledge } \\
\text { of English and American } \\
\text { cultures. Does not fully } \\
\text { understand the story even if it } \\
\text { is explicit. }\end{array}$ & $\begin{array}{l}\text { Does not show } \\
\text { interest in } \\
\text { communication. Can } \\
\text { express himself in } \\
\text { limited situations of } \\
\text { everyday issues. }\end{array}$ & $\begin{array}{l}\text { Not interested } \\
\text { in the culture of } \\
\text { another } \\
\text { country. } \\
\text { Indifferent to } \\
\text { other cultures. } \\
\text { Imprudent in } \\
\text { his remarks } \\
\text { towards other } \\
\text { peoples and } \\
\text { cultures. }\end{array}$ \\
\hline $\begin{array}{l}\text { Elementary } \\
\text { level }\end{array}$ & $\begin{array}{lr}\text { Has } & \text { basic } \\
\text { knowledge } & \text { in } \\
\text { linguistics, but } \\
\text { cannot explain } \\
\text { some of the } \\
\text { peculiarities } \\
\text { (structural levels, } \\
\text { normativity, } \\
\text { lexicology, etc.) }\end{array}$ & $\begin{array}{l}\text { Understands the text while } \\
\text { reading but not all the details } \\
\text { of it. Understands explicit } \\
\text { texts. Has basic knowledge } \\
\text { about the country } \\
\text { (holidays, traditions, common } \\
\text { characteristics of the people) } \\
\text { and can recognize them while } \\
\text { reading fiction. Can make a } \\
\text { socio-cultural portrait of the } \\
\text { personages and explain the } \\
\text { setting of an explicit story. }\end{array}$ & $\begin{array}{l}\text { Speaks English } \\
\text { fluently in everyday } \\
\text { situations. Can have } \\
\text { difficulties in } \\
\text { unfamiliar situations. } \\
\text { Understands the } \\
\text { main message of the } \\
\text { utterance. Open to } \\
\text { communication but } \\
\text { is not fully aware of } \\
\text { cultural differences. } \\
\text { Makes many } \\
\text { mistakes but the } \\
\text { speech is clear to the } \\
\text { audience }\end{array}$ & $\begin{array}{l}\text { Shows interest } \\
\text { in other } \\
\text { cultures. Show } \\
\text { interest to the } \\
\text { representatives } \\
\text { of other } \\
\text { cultures. }\end{array}$ \\
\hline
\end{tabular}




\begin{tabular}{|c|c|c|c|c|}
\hline $\begin{array}{l}\text { Sufficient } \\
\text { level }\end{array}$ & 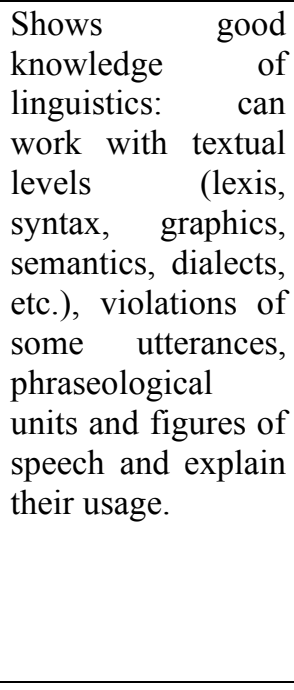 & $\begin{array}{l}\text { Can compare personal opinion } \\
\text { to other cultures' visions; Has } \\
\text { a general idea of the culture of } \\
\text { the language he/she studies as } \\
\text { well as the signs of } \\
\text { intercultural communication } \\
\text { and can use them in } \\
\text { intercultural communication. } \\
\text { Understands simple implicit } \\
\text { stories (Cat in the Rain by } \\
\text { Hemingway E.) } \\
\text { Can make a text analysis } \\
\text { within its sociocultural } \\
\text { characteristics (setting, } \\
\text { background, characters, } \\
\text { details) and other elements of } \\
\text { the story (title, details, etc.) }\end{array}$ & $\begin{array}{l}\text { Can easily } \\
\text { communicate in a } \\
\text { foreign language in } \\
\text { unfamiliar situations. } \\
\text { Does not have any } \\
\text { difficulty in } \\
\text { communication. The } \\
\text { mistakes in speech } \\
\text { are rare. The student } \\
\text { strives for } \\
\text { communication } \\
\text { when he/she can } \\
\text { fully apply cross- } \\
\text { cultural knowledge }\end{array}$ & $\begin{array}{l}\text { Careful, } \\
\text { diplomatic in } \\
\text { expressing } \\
\text { his/her opinion } \\
\text { towards other } \\
\text { cultures and } \\
\text { nations. } \\
\text { Shows } \\
\text { empathy and } \\
\text { interest in } \\
\text { another culture } \\
\text { and its } \\
\text { representatives. }\end{array}$ \\
\hline High level & $\begin{array}{l}\text { Proficient in } \\
\text { working with text } \\
\text { linguistics: always } \\
\text { sees the text } \\
\text { peculiarities (lexis, } \\
\text { syntax, graphics, } \\
\text { semantics, dialect, } \\
\text { etc.), the } \\
\text { normativity of } \\
\text { some expressions, } \\
\text { synonyms and } \\
\text { phraseological } \\
\text { units and can } \\
\text { explain their usage. }\end{array}$ & $\begin{array}{l}\text { Analyzes confidently been } \\
\text { implicit text within the } \\
\text { frameworks of its socio- } \\
\text { cultural peculiarities (setting, } \\
\text { background, personages, } \\
\text { details), as well as singles out } \\
\text { and analyzes the rest } \\
\text { parameters of the text (title, } \\
\text { detail, subject, idea, etc.) } \\
\text { Can follow the common rules, } \\
\text { find issues to discuss. } \\
\text { Understands complex implicit } \\
\text { stories (eg. Carcassone by } \\
\text { W.Folkner) } \\
\text { Can analyze implicit texts and } \\
\text { stories within its socio-cultural } \\
\text { background (setting, } \\
\text { background, personages, } \\
\text { details) and other elements of } \\
\text { the story (title, details, etc.) }\end{array}$ & $\begin{array}{l}\text { Can easily } \\
\text { communicate in a } \\
\text { foreign language in } \\
\text { unfamiliar situations. } \\
\text { Does not have any } \\
\text { difficulty in } \\
\text { communication. } \\
\text { There are practically } \\
\text { no mistakes in } \\
\text { speech. The student } \\
\text { possesses } \\
\text { extralinguistic } \\
\text { factors } \\
\text { communication of } \\
\text { when he/she can } \\
\text { fully apply his } \\
\text { knowledge about the } \\
\text { cross-cultural } \\
\text { difference }\end{array}$ & $\begin{array}{l}\text { Careful, } \\
\text { empathic in } \\
\text { expressing } \\
\text { his/her opinion } \\
\text { towards other } \\
\text { cultures and } \\
\text { nations. } \\
\text { Shows } \\
\text { empathy and } \\
\text { interest in } \\
\text { another culture } \\
\text { and its } \\
\text { representatives. }\end{array}$ \\
\hline
\end{tabular}

Source: Prepared by the authors

The questions to the text beside the ordinary interpretational may include:

- What historical episode makes the setting of the story? Find indication in the text;

- Why was narration entrusted to a young narrator, the child? Comment on the effects it achieves;

- $\quad$ Try to answer Charlie Stowe's final question "why his father had left the house again so late and who the strangers were." Do not offer a random guess. Find the indications of how the men were dressed, how they talked, what they discussed. What was Charlie's father? Collect all information about him, scattered in the text.

During the course, there were some participant observations included when the experts attended the lessons and described their impressions within the range of questions. After the 
course completed we arranged an internal and external evaluation with both the developed and free assessment forms. The students were offered to answer the questionnaire again and give examples of cultural implications in fiction.

In the third stage, we processed the empirical data, summarized and systematized the results of the study, analyzed theoretical and experimental findings.

\section{Results}

\section{The structure and the content of the model}

The assessment component includes the criteria and levels of IC development. The analysis of special literature on assessing the levels of IC has brought us to the conclusion that there are several approaches to assessing the level of IC development: the international language portfolio standard of Common European Framework (CEFR, 2001; INCA PROJECT, 2009), critical reflection, performance, indirect evaluation, teacher's observational, personal journals, etc. (DEARDOFF, 2006); video-recording and personal minutes of the students' performance; scenario-assessment scheme (VERJAN et al., 2011). The system of criteria of the international language portfolio is only partly applicable to our model as it demands an obligatory experience of intercultural communication that is not always possible for all Russian students of our country and, what is as well worth mentioning, there are no native speakers of English among them (KOZLOVA; KADYROVA; SAKHIBULLINA, 2019). So, the pilot experiment is also performed within simulated conditions as the only authentic representation of the foreign country and culture is the text.

So, we have developed a system of evaluation that relies on four basic elements of culture (awareness, attitude, skills, knowledge, and language proficiency) and our research objectives and concerning a range of factors that influence the formation of intercultural competence within the framework of teaching literary analysis. By a combination of the factors, we mean the process and content of teaching the analysis in a foreign language classroom in an optional presence of a real cross-cultural environment. So, the system of criteria included linguistic, informative-cognitive, communicative and evaluation criteria and low, elementary, basic, high and very high levels of intercultural competence. The key characteristics features concerning the levels of IC are presented in Table 1. 


\section{Evaluation results}

The evaluation was achieved through several quantitative and qualitative ways. Assessing the level of formation of intercultural competence of students before and after the experiment, as a basis, we have adopted a five-point scale of measurement. The experts assessed each criterion of IC development according to the assessment list, the results for each criterion were reduced to the average value of the criterion and were introduced into the final table. The distribution of the students' results according to the criteria of the development of students' intercultural competence is presented in Table 2 .

Table 2 - The dynamics of the average value within the criteria of IC development

\begin{tabular}{|l|c|l|c|l|}
\hline $\begin{array}{l}\text { Lexels } \\
\text { Stages }\end{array}$ & Linguistic & $\begin{array}{l}\text { Informative- } \\
\text { cognitive }\end{array}$ & Communicative & $\begin{array}{l}\text { Evaluation } \\
\text { (attitude) }\end{array}$ \\
\hline $\begin{array}{l}\text { Before the } \\
\text { experiment }\end{array}$ & 2,52 & 2,61 & 2,47 & 2,67 \\
\hline $\begin{array}{l}\text { After the } \\
\text { experiment }\end{array}$ & 3,26 & 3,25 & 3,05 & 3,02 \\
\hline
\end{tabular}

Source: Prepared by the authors

Figure 2 - The results of the IC development (Diagram)

The dynamics of students' distribution according to the level of intercultural competence (\%)

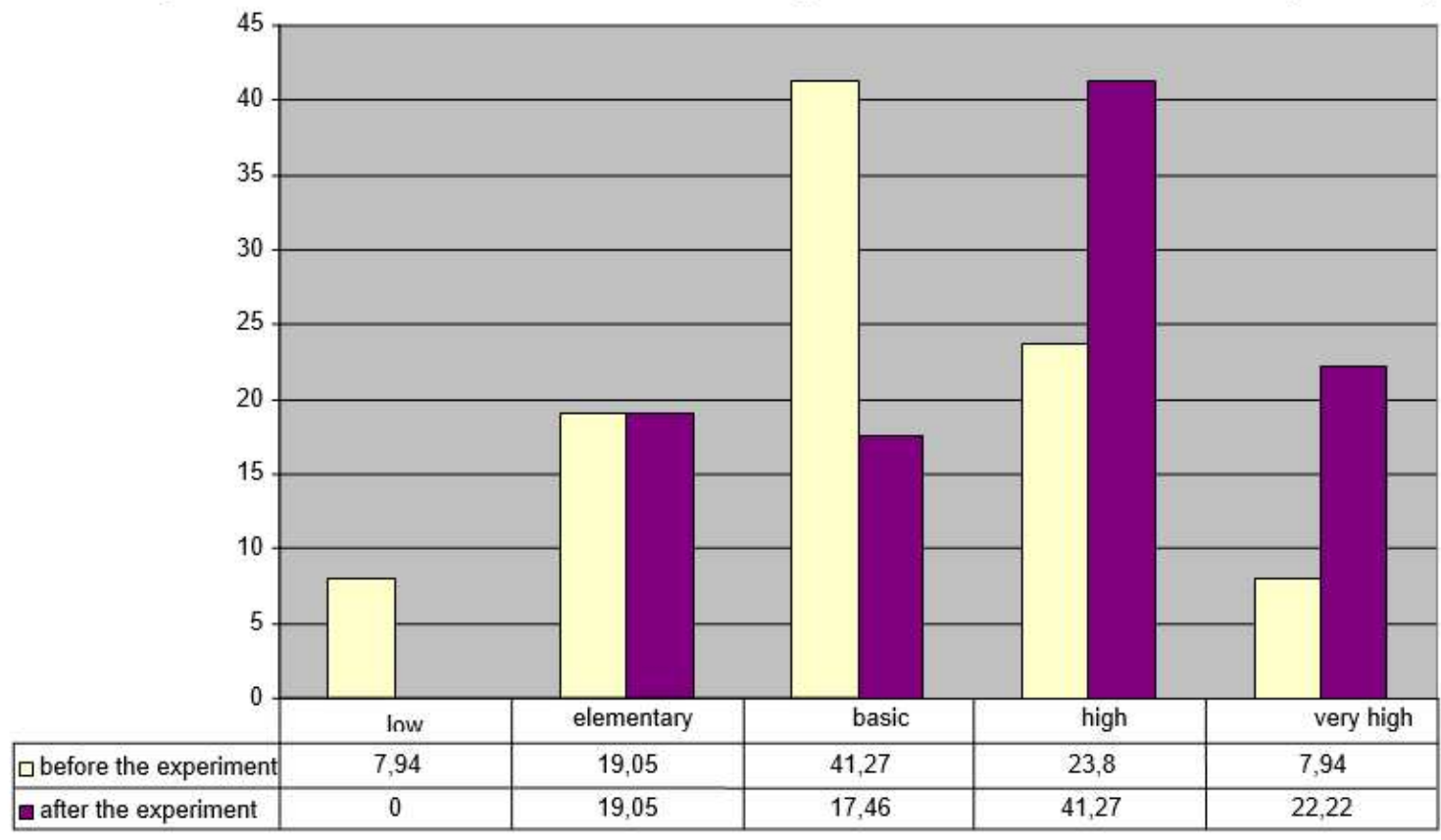

Source: Prepared by the authors 
The statistical analysis of the experimental data in the form of unpaired Student's t-test helped to test the hypothesis that the post-experimental mean values of the tested parameters are significantly higher than pre-experimental ones. The test showed statistically significant differences in all parameters. The values of the parameters after the experiment are higher than before the experiment. The statistical significance is at the level $\mathrm{t} e \mathrm{mp} .>\mathrm{t}$ crit. at the level of reliability of $0.999, \mathrm{p}<0.001$ for the averages of expert evaluation, and $\mathrm{t} e \mathrm{mp}$. $>\mathrm{t}$ crit. at the level of reliability of $0.999, \mathrm{p}<0.001$, which does not contradict the statistical results of the experiment.

The quantitative results of intercultural competence development are shown graphically in Figure 2. As the basic assessment was performed through the expert evaluation, the final distribution within the levels of intercultural competence is based on the results of expert evaluations. The results of the students' questionnaire confirmed the results of the basic experiment.

So, the results show a contradiction: on the one hand, the society requires an improved level of IC, that means feeling confident in diverse conditions of cross-cultural environment, necessity to be prepared to communicate efficiently with the representatives of other cultures and on the other hand, we observe the insufficient progress of the educational approach to achieve this objective. So, we may conclude that the significant potential of authentic literature as a means of developing students' intercultural competence may contribute to the scientifically grounded system of the practical development of IC in higher school.

\section{Conclusion}

The author intended to design a didactic model that should develop students' IC through literary analysis and interpreting foreign literature. The model that would provide knowledge, skills, the system of values, reflection and positive attitude to the culture under study within the systemic, activity and cultural approach. The second task was to test the model through the developed forms, methods and tools in teaching literary analysis paying special attention to culture-related aspects. The model and the efforts proved to be effective. The quantitative results show positive dynamics in developing students' IC. 


\section{Recommendations}

The article can be useful valuable for the specialists in intercultural and other culturerelated environment, to foreign language teachers and teachers of literature and linguistics as the results of the study are practically applicable in any language classroom and can help to solve the actual problem of bringing up an all-round personality for today's rapidly changing multinational world to communicate effectively.

The article can be valuable for the specialists of intercultural and other culture-related abilities, to unknown dialect instructors and educators of writing and semantics as the aftereffects of the examination are for all intents and purposes material in any language study hall and can assist with taking care of the real issue of raising a versatile character for the present quickly changing worldwide world to impart viably.

ACKNOWLEDGEMENTS: The work is performed according to the Russian Government Program of Competitive Growth of Kazan Federal University.

\section{REFERENCES}

ABUZYAROVA, D. L.; TAKHTAROVA, S. S.; KUZMINA, O. D. Concept ordnung and german communicative style: problems of intercultural communication. Opcion, v. 35, n. esp. 22, p. 255-266, 2019.

BANDURA, A. Social foundations of thought and action: a social cognitive theory. Englewood Cliffs, NJ: Prentice Hall, 1986.

BYRAM, M.; GRIBKOVA, B.; STARKEY, H. Developing the intercultural dimension in language teaching. Strasbourg: Language Policy Division Directorate of School, Out-ofSchool and Higher Education DGIV Council of Europe, 2002

BYRAM, M.; NICHOLS, A.; STEVENS, D. Developing intercultural competence in practice. Clevedon, UK: Multilingual Matters, 2001.

CEFR. Common European Framework of reference for languages: learning, teaching assessment. Cambridge University Press, 2001. Available: www.coe.int/lang-CEFR. Access: 10 Dec. 2020.

DEARDORFF, D. Assessing intercultural competence. New Directions for Institutional Research, n. 149, p. 65-79, 2011. DOI: doi.org/10.1002/ir.381

DIMITROVA-GYUZELEVA, S. A reactive approach to teaching english through literature. In: BETA-IATEFL ANNUAL INTERNATIONAL CONFERENCE, 24., 2015, Sófia. Proceedings [...]. Sófia, Bulgaria: University of National and World Economy, 2015. 
Available: http://www.beta-iatefl.org/cogitoergosum/wp-content/uploads/2015/08/BETAIATEFL-Newsletter_July_August_2015.pdf. Access: 10 Dec. 2020.

FANTINI, A. E. Assessing intercultural competence: a YOGA Form. Brattleboro, VT: TESOL, 1999.

FANTINI, A. E. New ways in teaching culture. Alexandria, VA: TESOL, 1997.

HOLLAND, C. J.; KOBASIGAWA, A. Theories of learning: a comparative approach. Itasca, 1980.

INCA PROJECT. 2009. Available: https://ec.europa.eu/migrant-integration/librarydoc/theinca-project-intercultural-competence-assessment. Access: 10 Dec. 2020.

KOZLOVA, Y. A.; KADYROVA, A. A.; SAKHIBULlinA, K. A. Problems of testing application in foreign language learning control. Humanities and Social Sciences Reviews, v. 7 , n. 6 , p. 53-59, 2019.

NIKOLAEVA, O. Anti-drug propaganda by means of teaching english to the students. Philological Sciences. Issues of Theory and Practice, v. 8-1, n. 26, p. 123-127, 2013.

PASSOV, E. I. A communicative method of teaching speaking a foreign language. Prosveschenie. Moscow, 1985.

RAKHIMOV, A. Z. Psychodidactics: teaching material. UFA, 1996.

SABIROVA, D. R. et al. Comprehension of the english national character in building professional linguistic culture. Journal of Educational and Social Research, v. 9, n. 3, p. 101-106, 2019.

VERJANS, S. et al. Online CEF-based assessment of oral proficiency for intercultural professional communication. In: CEFcult Framework and Methodology. 2011. Retrieved from:

https://www.academia.edu/2833714/Online_CEF_based_assessment_of_oral_proficiency_for _intercultural_professional_communication. Access: 10 Dec. 2020. 


\section{How to reference this article}

IBRAGIMOVA, A. N.; KADYROVA, A. A. Developing Intercultural Competence: a model based on introducing a literary analysis in a foreign language classroom. Rev. EntreLínguas, Araraquara, v. 7, n. esp. 3, e021046, Sep. 2021. e-ISSN: 2447-3529. DOI: https://doi.org/10.29051/el.v7iesp.3.15704

Submitted: 10/01/2021

Required revisions: 20/03/2021

Approved: 23/06/2021

Published: 01/08/2021 